\title{
Antioxidant Activity and Chemical Composition of Extracts from Fruiting Bodies of Xylotrophic Fungi Growing on Birch
}

\author{
Alexander A. Ermoshin*a, \\ Irina S. Kiseleva ${ }^{a}$, Irina V. Nikkonena, \\ Dominique S. Nsengiyumva ${ }^{a}$, Shen Duan ${ }^{b}$, \\ Chaomei Ma ${ }^{\mathrm{b}}$ and Vladimir P. Kurchenko ${ }^{c}$ \\ ${ }^{a}$ Ural Federal University \\ Ekaterinburg, Russian Federation \\ ${ }^{b}$ Inner Mongolia University \\ Hohhot, People's Republic of China \\ ${ }^{c}$ Belarus State University \\ Minsk, Belarus Republic
}

Received 07.04.2021, received in revised form 04.05.2021, accepted 14.07.2021

\begin{abstract}
The search for new natural sources of biologically active substances is a major issue in pharmaceutical industry. Xylotrophic basidiomycetes are common in forests worldwide, but as a prospective raw source of biologically active compounds they have not been studied as extensively as plants and other groups of fungi. The study is aimed to determine the chemical composition and antioxidant activity of extracts from 10 species of tinder fungi growing on birch and common in the forests in Russia. The chaga muchroom (Inonotus obliquus), traditionally used in medicine, was chosen as a standard species. Extracts from fruiting bodies were obtained with water or $95 \%$ ethanol. They contained 4 to 8 types of free amino acids including 2 to 6 essential ones. Perennial basidiocarps were shown to be richer in phenolic compounds and poorer in amino acids than annual ones. Alkaloids and saponins were found in perennial basidiocarps of two species, saponins were also found in annual basidiocarps of one species. Water and alcohol extracts differed in composition and concentration of extractives, and showed different antioxidant (inhibition of lipid peroxidation) and antiradical (ABTS-test, inhibition of NO production) activity. This way it was shown that the nature of the solvent extraction agent is important for the manifestation of biological activity. In most tests, water extracts from chaga showed better antioxidant properties; extracts from Piptoporus betulinus
\end{abstract}

(C) Siberian Federal University. All rights reserved

This work is licensed under a Creative Commons Attribution-NonCommercial 4.0 International License (CC BY-NC 4.0).

* Corresponding author E-mail address: Alexander.Ermoshin@urfu.ru

ORCID: 0000-0003-2784-4898 (Ermoshin A.A.); 0000-0002-8709-5203 (Kiseleva I.S.); 0000-0002-4859-2389 (Kurchenko V.P.); 0000-0003-1189-7901 (Ma C.) 
and Fomitopsis pinicola were also effective as antioxidants, which may be promising avenues for future research.

Keywords: xylotrophic fungi, chaga, phenols, antioxidant activity, amino acids, qualitative composition.

Acknowledgements. The work was supported by the Ministry of Science and Higher Education of the Russian Federation, Project No. FEUZ-2021-0014. The authors are deeply grateful to Professor Viktor Mukhin (Ural Federal University, Ekaterinburg) for his invaluable assistance in species identification.

Citation: Ermoshin A. A., Kiseleva I. S., Nsengiyumva I. V., Nsengiumva D. S., Duan S., Ma C., Kurchenko V.P. Antioxidant activity and chemical composition of extracts from fruiting bodies of xylotrophic fungi growing on birch. J. Sib. Fed. Univ. Biol., 2021, 14(3), 339-353. DOI: 10.17516/1997-1389-0354

\title{
Антиоксидантная активность и химический состав экстрактов ксилотрофных грибов Среднего Урала, произрастающих на березе
}

\author{
А. А. Ермошин ${ }^{\text {, И. С. Киселёва }}{ }^{a}$, \\ И. В. Никконен ${ }^{\mathrm{a}}$, Д. С. Нсенгиумва ${ }^{\mathrm{a}}$, \\ Ш. Дуан \\ ${ }^{a}$ Уральский федеральнылй университет \\ Российская Федерачия, Екатеринбург \\ ${ }^{6}$ Университет Внутренней Монголии \\ Китайская Народная Республика, Хух-Хото \\ ${ }^{6}$ Белорусский государственный университет \\ Республика Беларусь, Минск
}

Аннотация. Поиск новых природных источников биологически активных веществ остается актуальной проблемой. Ксилотрофные базидиомицеты широко распространены в лесах, но как сырье для получения биологически активных соединений они менее изучены, чем растения и другие группы грибов. Цель исследования - изучение химического состава и антиоксидантной активности экстрактов 10 видов трутовых грибов, произрастающих на березе и широко распространенных в лесах России. В качестве вида сравнения выбрана чага Inonotus obliquus, традиционно используемая в медицине. Экстракцию веществ из плодовых тел проводили водой или 95\%-ным этанолом. В экстрактах обнаружено от 4 до 8 типов свободных аминокислот, в том числе от 2 до 6 незаменимых. Показано, что многолетние базидиокарпы богаче фенольными соединениями и беднее аминокислотами, чем однолетние. В многолетних базидиокарпах двух видов были обнаружены алкалоиды и сапонины; также сапонины обнаружены у одного вида с однолетними базидиокарпами. Водные и спиртовые экстракты различались по составу и концентрации экстрактивных веществ и проявляли разную антиоксидантную (ингибирование 
перекисного окисления липидов) и антирадикальную (ABTS-тест, ингибирование продукции NO) активность. Таким образом, природа экстрагента имеет значение для проявления биологической активности. В большинстве тестов водные экстракты чаги показали наилучшие антиоксидантные свойства, однако с ними могут быть сопоставимы экстракты Piptoporus betulinus и Fomitopsis pinicola, что определяет перспективы их дальнейшего изучения.

Ключевые слова: ксилотрофные грибы, чага, фенолы, антиоксидантная активность, аминокислоты, качественный состав.

Благодарности. Работа выполнена при поддержке Министерства науки и высшего образования Российской Федерации, проект № FEUZ-2021-0014. Авторы выражают глубокую признательность профессору, доктору биологических наук Виктору Андреевичу Мухину за помощь в идентификации видов.

Цитирование: Ермошин, А. А. Антиоксидантная активность и химический состав экстрактов ксилотрофных грибов Среднего Урала, произрастающих на березе / А. А. Ермошин, И. С. Киселёва, И. В. Никконен, Д. С. Нсенгиумва, Ш. Дуан, Ч. Ма, В. П. Курченко // Журн. Сиб. федер. ун-та. Биология, 2021. 14(3). С. 339-353. DOI: 10.17516/1997-1389-0354

\section{Introduction}

Industrial development and urbanization affect negatively the biota. Pollution causes oxidative stress in living organisms, which leads to metabolic disorders and pathological conditions in them. This explains high demand in biologically active substances (BAS) with antioxidant and antiradical activity. Artificial synthesis of such compounds in pharmaceutical industry and biotechnology poses a significant challenge, therefore, active search for natural sources of BAS is of great interest.

Higher plants with rich secondary metabolism are major sources of natural BAS. Higher fungi also have a wide range of secondary metabolic pathways, but they have been studied as a potential source of BAS to a much lesser extent than plants. Fungi are known to have been applied in Oriental medicine (Japan, Korea, Vietnam and especially China) and traditional East-European medicine quite a lot, although not as extensively as plants (Lindeqist et al., 2005; Blagodatski et al., 2018). In Russia, the chaga muchroom (Inonotus obliquus (Ach. ex Pers.) Pil.) has been long used to treat tumors and inflammations. It has been proven that chaga preparations have a pronounced anticancer and immunomodulatory effect. For this reason, they are used as a prophylactic agent, as well as a component of complementary therapy (Tsai et al., 2017; Gery et al., 2018). In China and Japan, the reishi (also known as lingzhi) mushroom (Ganoderma lucidum (Curtis) P. Karst) is widely used for medical treatment. It has been shown that fruiting bodies of ganoderma contain high concentrations of steroids and triterpenes (triterpenic acids and alcohols), which have a pronounced anticancer effect (Zhao et al., 2019). In Japan, extracts of glycoprotein from biotechnologically cultivated Trametes versicolor (L.) Lloyd are used as anticancer drugs (Ho et al., 2005). Other types of wood-destroying (tinder) fungi are used in both traditional and modern medicine, but are less studied (Gruendemann et al., 2020; Payamnoor et al., 2020).

Xylotrophic basidiomycetes found in Russian forests are promising for study with respect to content of BAS and their antioxidant and antiradical activity. Considering the fact 
that a significant part of Russia is covered with forests, there is a huge potential for raw materials from them. The paper aims to determine the antioxidant and antiradical properties of extracts obtained from fruiting bodies of the most common xylotrophic basidiomycetes and to study their chemical composition qualitatively and quantitatively.

\section{Materials and methods}

\section{Biological material}

Fruiting bodies of basidiomycetes growing on birch (Betula pendula Roth.) were used as material for extraction. They were collected in mixed forest with dominant pine (Pinus sylvestris L.) in the vicinity of the Ural Federal University biological station (Russia, Sverdlovsk Oblast, the village of Klyuchi, near the city of Dvurechensk $56^{\circ} 37^{\prime} 44^{\prime \prime} \mathrm{N}, 61^{\circ} 03^{\prime} 53^{\prime \prime}$ E). Fruiting bodies were collected from tree trunks at the height of up to 2 $\mathrm{m}$. Depending on the species abundance, samples were collected from 10-30 trees, 20-50 fruiting bodies each. The material was fixed by heating at $50{ }^{\circ} \mathrm{C}$ for $1 \mathrm{~h}$, air-dried to a constant mass, ground and randomized.

Ten species of fungi were studied: I. obliquus (the chaga mushroom), Fomes fomentarius (L.) Fr., Fomitopsis pinicola (Sw.) P. Karst, Phellinus cinereus (Niemelä) Parmasto, Piptoporus betulinus (Bull.) P. Karst., Trametes versicolor, T. pubescens (Schumach.) Pilát, T. gibbosa (Pers.) Fr., Trichaptum pergamenum (Fr.) G. Cunn., Stereum subtomentosum Pouzar. The first four species have perennial basidiocarps, the others are annuals. The chaga has been commonly used in traditional and modern medicine and is well studied; for this reason, we used it as a standard species.

Species were identified using identification keys and compared with the species description (Storozhenko et al., 2014; Kotkova et al., 2015). Samples were validated by mycologist,
Professor V. A. Mukhin (Ural Federal University, Ekaterinburg).

\section{Extraction}

A solvent extraction agent - distilled water or $95 \%$ ethanol $(3 \mathrm{~mL})$ - was added to dry biomass of fruiting bodies $(150 \mathrm{mg})$. The mixture was treated with ultrasound for $15 \mathrm{~min}$ $(570 \mathrm{~W})$ and kept for $25 \mathrm{~min}$ in a water bath at $50{ }^{\circ} \mathrm{C}$, occasionally stirred. Then the mixture was centrifuged. Extraction was repeated 3 more times, supernatants were pooled, and volume was adjusted to $15 \mathrm{~mL}$. One milliliter of the obtained extract corresponded to $10 \mathrm{mg}$ of dry biomass (DW) of the fungus.

\section{Antioxidant activity}

Antiradical activity was determined by the ability to inhibit the formation of the ABTS-radical - 2,2'-azino-bis (3-ethylbenzothiazoline-6-sulfonic acid) and was expressed as a percentage; complete inhibition of radical formation was taken as $100 \%$ (Re et al., 1999).

The ability to suppress the formation of nitric oxide was determined in the model with sodium nitroprusside. Complete suppression was taken as $100 \%$. Negative values indicate the stimulation of nitric oxide production (Umamaheswari, Chatterjee, 2008).

Membrane lipid peroxidation (LPO) was modeled in the reaction of free tween- 80 oxidation with atmospheric oxygen in the presence of iron ions, followed by determination of formed malondialdehyde in the reaction with thiobarbituric acid. Complete suppression of tween- 80 oxidation was taken as $100 \%$. Negative values correspond to prooxidant activity of the extract and stimulation of LPO processes (Umamaheswari, Chatterjee, 2008).

The total reduction potential was determined by the formation of molybdenum 
blue. The absence of reducing power was taken as 0 conventional units. Positive values indicated the reduction potential of the examined extracts (Umamaheswari, Chatterjee, 2008).

Qualitative analysis

of the chemical composition

To detect alkaloids, precipitation reactions were carried out with iodide complexes of mercury, bismuth, cadmium, phosphotungstic, phosphoromolybdic salts and picric acids, tannin, and iodine (Sorescu et al., 2018). The reactions were carried out by the micro method using an immunological plate. The presence of alkaloids was justified if the analytical effect was observed for 4 or more reactions out of 8 carried out.

The presence of phenols was determined by the reaction with iron (III) chloride; flavonoids were identified by the Synod-test (reduction with molecular hydrogen to red flavones in an acidic medium), by increased yellow coloring with lead acetate in an alkaline medium (Shaikh, Patil, 2020), and by aluminum chloride test (Sheel et al., 2014).

Saponins were determined by the formation of foam upon shaking with water (Sorescu et al., 2018) and formation of a precipitate with lead acetate (Pavlovskaya et al., 2012).

\section{Paper chromatography}

For paper chromatography, an aliquot of the extract equivalent to $4 \mathrm{mg}$ DW of fungi was applied onto chromatographic paper. Separation was carried out by descending chromatography in $95 \%$ ethanol for $15 \mathrm{~h}$. Chromatograms were dried and sprayed with $0.2 \%$ ninhydrin in acetone. Amino acids were identified by comparing the Rf values of chromatographically separated substances and standards.

Phenolic compounds were determined after the exposure to UV irradiation before and after treatment with ammonia vapor. Phenols were identified based on the color of the spot, its fluorescence and a change in color intensity. Phenolic acids and alcohols fluoresced in blue light. Polyphenols were detected as gray and brown spots (Sokolova et al., 2018).

\section{Quantitative analysis}

of the composition of extracts

The content of phenolic compounds was determined spectrophotometrically with the Folin-Chocalteu reagent, with gallic acid as the standard (Larayetan et al., 2019).

Flavonoids were determined spectrophotometrically as complexes with aluminum chloride, with rutin as the standard (Larayetan, 2019).

Free amino acids were determined spectrophotometrically with the ninhydrin reagent, with glycine as the standard (Kotova et al., 2020).

All quantitative measurements were performed using an Infinite Tecan M 200 Pro microplate spectrophotometer (Tecan, Austria).

\section{Statistical data processing}

Quantitative analyzes were done in 4-5 (identification of phenols, flavonoids, amino acids) or 6-8 (antioxidant reactions) analytical replicates. Statistical significance of the differences was determined by the nonparametric Mann-Whitney $U$-test using the Statistica 8.0 and MS Excel 2013 software packages. The values are presented as the arithmetic mean and its standard error (SE).

\section{Results and discussion}

\section{Antioxidant activity of extracts}

An assay of antioxidant activity was carried out in water and ethanol extracts from 10 xylotrophic fungi species growing on birch in the forests of the Middle Urals (Table 1). The reducing power of the extracts varied depending both on the species and type of the solvent extraction agent. 
Table 1. Antioxidant activity of water and ethanol extracts from fruiting bodies of tinder fungi

\begin{tabular}{c|cc|cc}
\hline \multirow{2}{*}{ Species } & \multicolumn{2}{|c|}{ Reduction potential, c. u. } & \multicolumn{2}{c}{ Inhibition of LPO, \% } \\
\cline { 2 - 4 } & Ethanol & Water & Ethanol & Water \\
\hline I. obliquus & $14.0 \pm 2.8$ & $118.4 \pm 13.3^{\mathrm{x}}$ & $9.4 \pm 2.8$ & $43.4^{\mathrm{y}} 3^{\mathrm{x}}$ \\
F. fomentarius & $123.3 \pm 7.9^{*}$ & $48.6 \pm 6.9^{* \mathrm{x}}$ & $16.1 \pm 11.0$ & $3.9 \pm 2.0^{* \mathrm{x}}$ \\
F. pinicola & $52.4 \pm 3.4^{*}$ & $23.8 \pm 1.1^{* \mathrm{x}}$ & $21.2 \pm 7.0^{*}$ & $3.3 \pm 2.0^{* \mathrm{x}}$ \\
P. betulinus & $129.0 \pm 5.0^{*}$ & $115.2 \pm 8.1$ & $-0.5 \pm 1.0^{*}$ & $-8.0^{*} \pm 2.4^{* \mathrm{x}}$ \\
P. cinereus & $11.9 \pm 6.4^{*}$ & $32.0 \pm 2.6^{* \mathrm{x}}$ & $13.1 \pm 2.3$ & $1.3 \pm 1.0^{* \mathrm{x}}$ \\
S. subtomentosum & $47.4 \pm 2.7^{*}$ & $73.9 \pm 2.9^{* \mathrm{x}}$ & $-5.1 \pm 2.5^{*}$ & $1.3 \pm 1.0^{*}$ \\
T. gibbosa & $26.2 \pm 5.6^{*}$ & $28.8 \pm 12.0^{*}$ & $-4.1 \pm 2.5^{*}$ & $-4.1 \pm 3.4^{*}$ \\
T. pergamenum & $40.8 \pm 8.3^{*}$ & $59.7 \pm 8.3^{*}$ & $-1.2 \pm 2.0^{*}$ & $-4.6 \pm 2.0^{*}$ \\
T. pubescens & $31.3 \pm 4.8^{*}$ & $63.6 \pm 20.0$ & $-10.4 \pm 0.2^{*}$ & $9.5 \pm 0.6^{* \mathrm{x}}$ \\
T. versicolor & $18.8 \pm 3.2^{*}$ & $68.0 \pm 6.1^{* \mathrm{x}}$ & $-1.9 \pm 1.5^{*}$ & $-10.0 \pm 5.0^{*}$ \\
\hline
\end{tabular}

Note. Results are expressed as mean \pm SE. Values marked by special symbols are significantly different $(p<0.05)$ from other

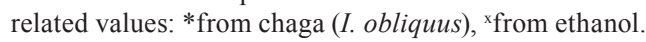

Water extracts from the chaga, T. versicolor and $P$. cinereus had greater reducing power than ethanol ones (8.4 times, 3.6 times and 2.7 times greater, respectively), while water extracts from $F$. fomentarius and $F$. pinicola were 2.5 times less active than ethanol ones. For the other species, reducing power of aqueous and alcoholic extracts differed less markedly. A comparison of water extracts from different species showed that the chaga and $P$. betulinus had the highest reducing power. Ethanol extracts from $T$. versicolor and $P$. cinereus practically did not differ from ethanol chaga extracts in terms of their reduction potential. Ethanol extracts from other species showed a significantly greater reducing power than those from the chaga. P. betulinus ethanol extract showed the highest activity. It was 9 times more active than chaga extract. Thus, the highest reducing power was found in water chaga extract, and water and ethanol extracts from $P$. betulinus (Table 1).

Membrane lipid peroxidation (LPO) is one of the nonspecific responses in cells under oxidative stress. Water and ethanol extracts from the investigated fungi were tested as antioxidants in the LPO model. Among water extracts, the best result was shown for chaga - the amount of malondialdehyde (MDA) formed in the LPO reaction was decreased by $43 \%$ in the presence of chaga extract. Water extract from T. pubescens inhibited lipid peroxidation by $9.5 \%$, while water extracts from the other species either did not suppress the formation of MDA, or even stimulated it, i. e., they were prooxidants (Table 1).

Ethanol chaga extract inhibited the formation of MDA to a lesser extent (9.5\%) than its aqueous extract. Extracts from $F$. fomentarius and $P$. cinereus showed approximately the same efficiency (16 and $13 \%$ ). Ethanol extract from $F$. pinicola was more active than the water one (21\% versus $3 \%$ ). The rest of the samples revealed a slight prooxidant effect and stimulated formation of MDA by $1-10 \%$.

Thus, not all samples with high reduction potential inhibited the formation of MDA. Some of them had a prooxidant effect. In some cases, fungal extracts could both stimulate and inhibit the formation of MDA, depending on the solvent used (Table 1).

In addition to reactive oxygen species, oxidative stress can be caused by reactive 


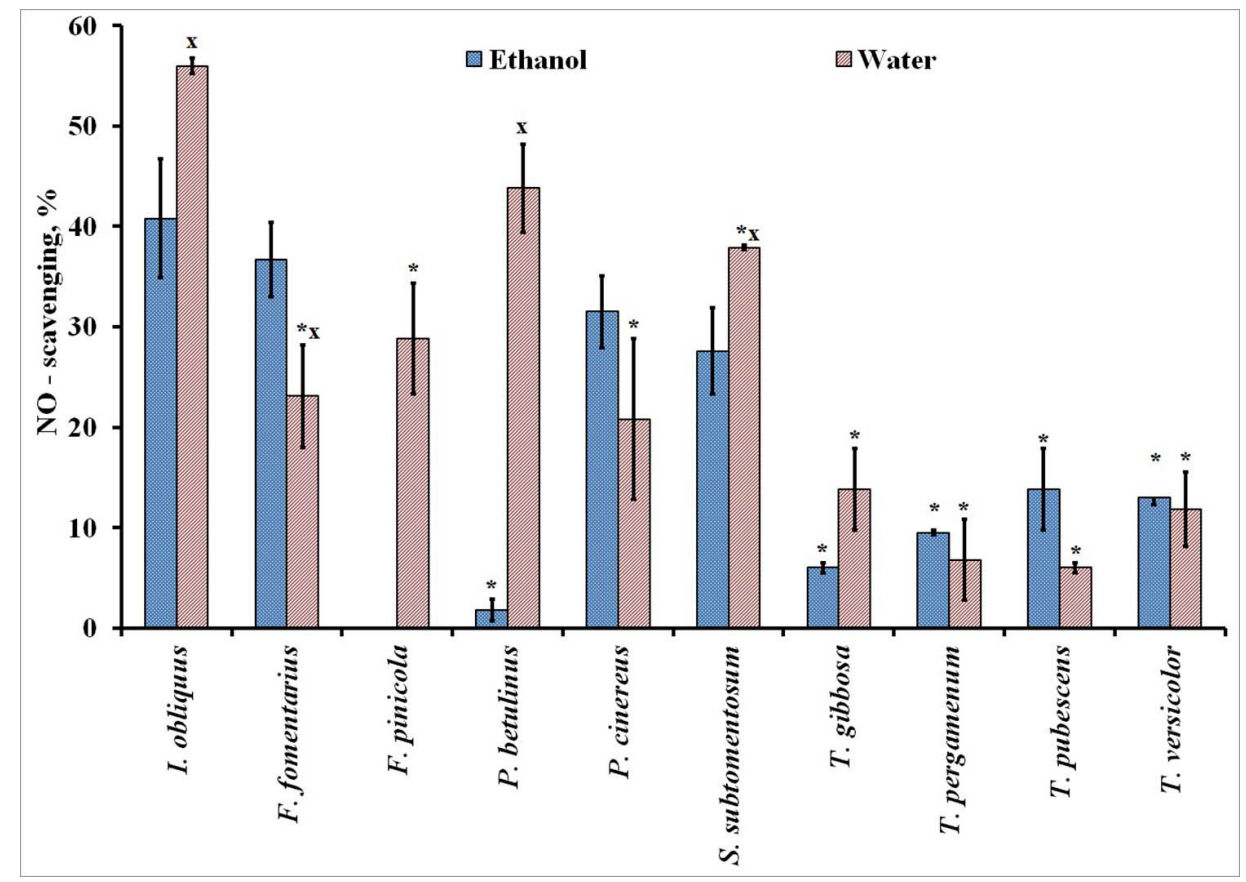

a

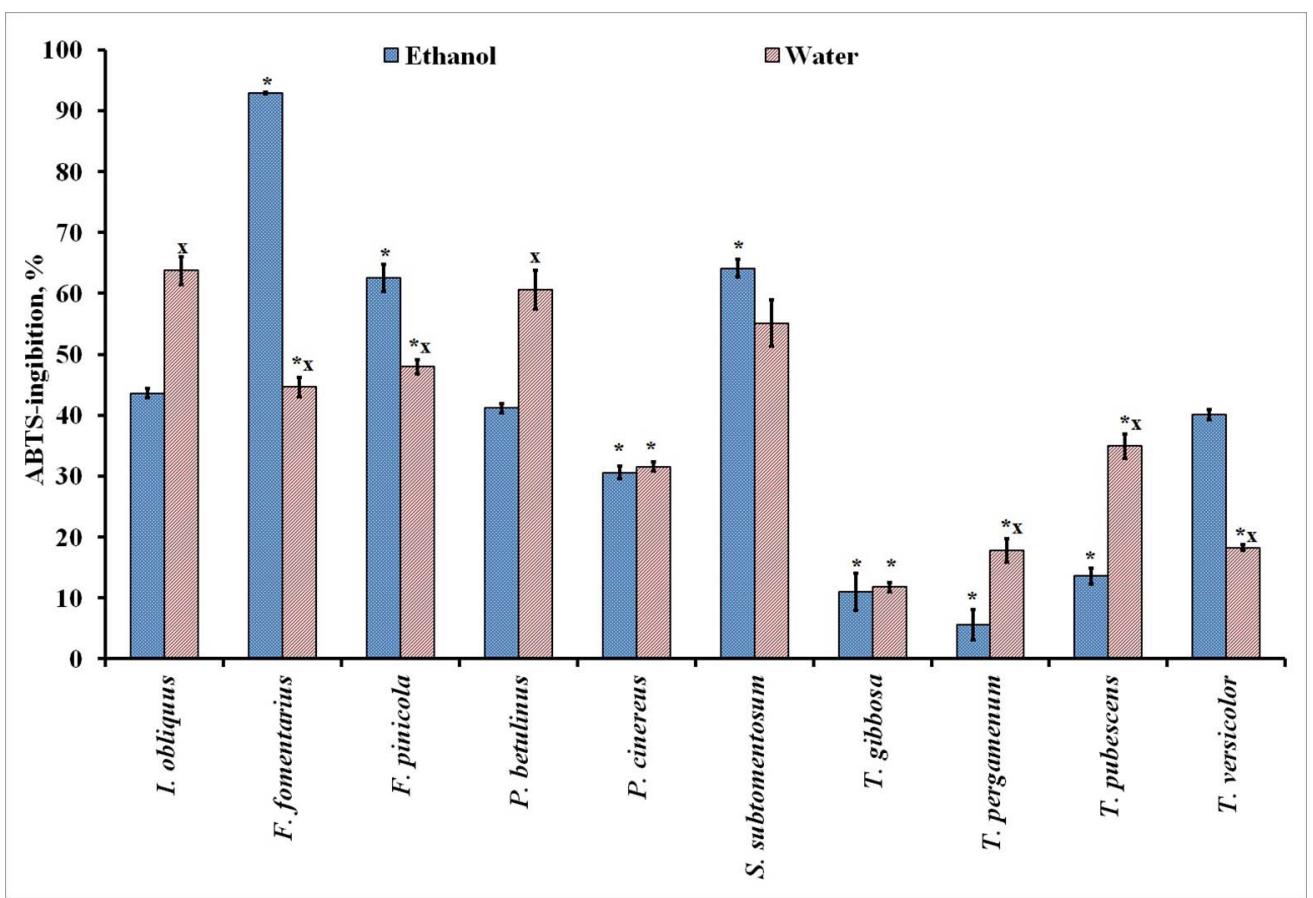

b

Fig. 1. Antiradical activity of extracts from fruiting bodies of tinder fungi: inhibition of NO (a) and ABTS-radicals production (b). Results are expressed as mean \pm SE. Values marked by special symbols are significantly different $(p<0.05)$ from other related values: *from chaga (I. obliquus), ${ }^{x}$ from ethanol 
nitrogen species (Brieger et al., 2012). An analysis of the extracts' ability to inhibit nitrogen oxide production in vitro showed that the aqueous chaga extract had the highest effect - NO production was decreased by $56 \%$ (Fig. 1a). The extracts from P. betulinus and S. subtomentosum showed a slightly lower activity $(43.8 \%$ and $37.9 \%$ decrease in NO production, respectively). Water extracts from other fungi also inhibited NO production, but they were at least 2 times less effective than the chaga extract.

Ethanol extracts inhibited the formation of nitric oxide to a lesser extent than water ones. The highest inhibitory activity was shown by ethanol extracts from I. obliquus (40.8\%), F. fomentarius (36.7 \%) and P. cinereus (31.5\%) (Fig. 1a).

In the test for suppression of the ABTS radical production, the water chaga extract was 1.5 times more active than its ethanol extract, in contrast to $F$. fomentarius; its aqueous extract was 2 times less active than the ethanol one (Fig. 1b). This corresponds to the reducing power of extracts (Table 1). The activity of $F$. fomentarius ethanol extract was maximal in comparison with other species (about $90 \%$ ) and exceeded the activity of the water chaga extract by 1.5 times. F. pinicola, P. betulinus,
S. subtomentosum showed antiradical activity to be comparable to that of chaga. Extracts from the other species were significantly inferior to chaga in terms of this effect (Fig. 1b).

\section{Chemical composition of extracts}

\section{from fruiting bodies}

of xylotrophic basidiomycetes

Antioxidant activity in different fungi may be associated with production of different compounds. Previously, using gas chromatography combined with mass spectrometry we showed that methanol extracts from xylotrophic fungi contain more than 100 minor and basic compounds, including free carbohydrates arabinitol and sorbitol, hexaand octodecanoid acids and their derivatives, ergosterol and its derivatives, lupeol and other secondary compounds (Kurchenko et al., 2020). The results of quality tests for biologically active substances in the studied extracts are presented in Table 2. Metabolite composition of aqueous and ethanol extracts from the same species was similar.

Alkaloids were found only in two species, $F$. fomentarius and F. pinicola. F. fomentarius, $P$. betulinus and $F$. pinicola showed the presence

Table 2. The qualitative composition in extracts from fruiting bodies of tinder fungi (similar in water and ethanol extracts)

\begin{tabular}{|c|c|c|c|c|c|c|c|c|c|c|}
\hline \multirow[b]{2}{*}{ Group of compounds } & \multicolumn{10}{|c|}{ Fungi species } \\
\hline & 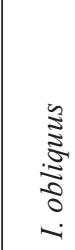 & 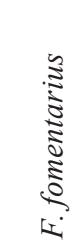 & 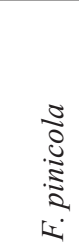 & 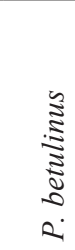 & 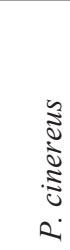 & 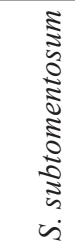 & 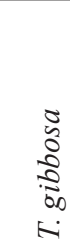 & 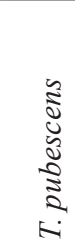 & 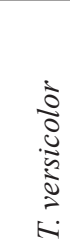 & $\begin{array}{c}\text { I } \\
\text { ఏ } \\
\vdots \\
\vdots \\
0 \\
0 \\
\vdots \\
\vdots \\
-1\end{array}$ \\
\hline Alkaloids & - & + & + & - & - & - & - & - & - & - \\
\hline Flavonoids & - & + & - & - & - & - & - & - & - & - \\
\hline Saponins & - & + & + & + & - & - & - & - & - & - \\
\hline Simple phenols & + & + & + & + & + & - & - & - & - & - \\
\hline
\end{tabular}

Note. $(+)$ compound is determined; $(-)$ compound is not determined 


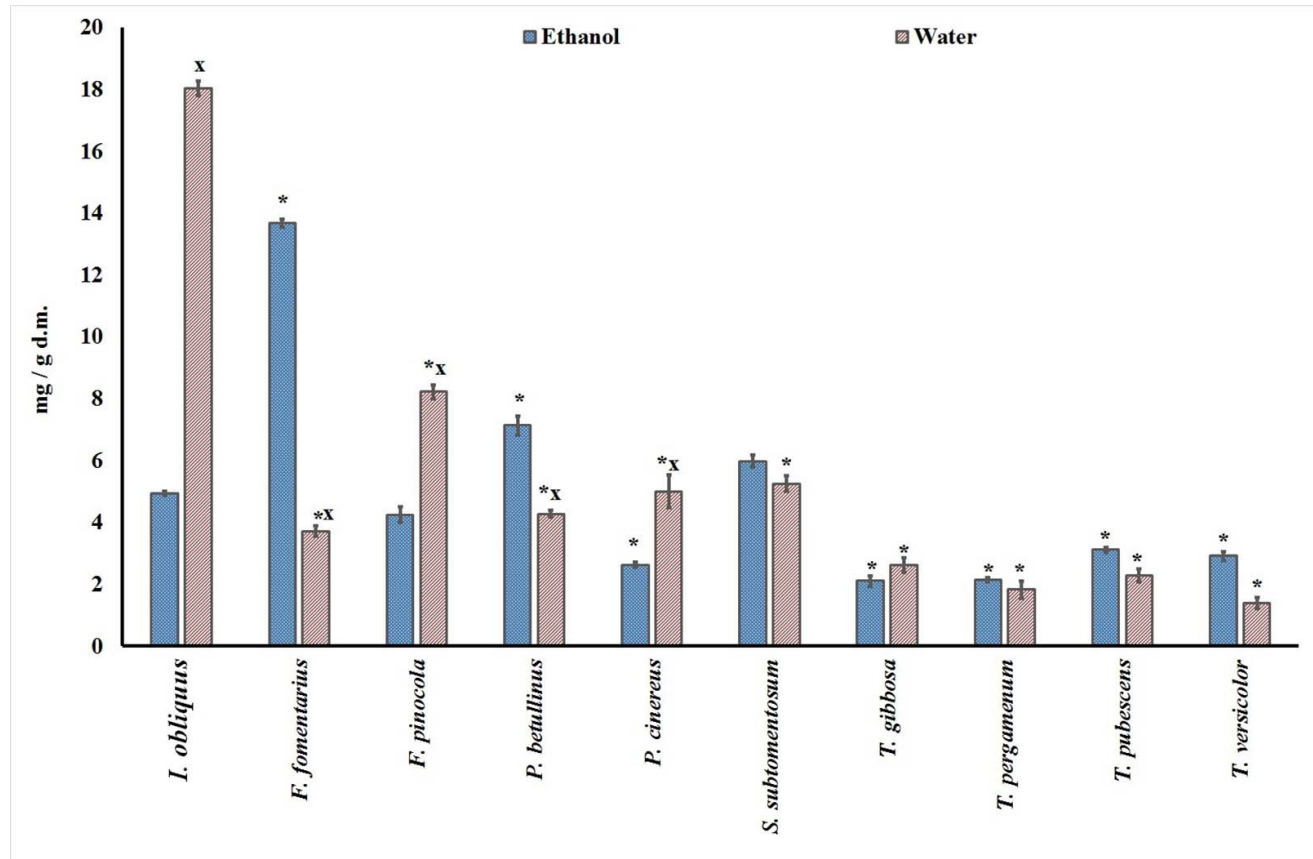

a

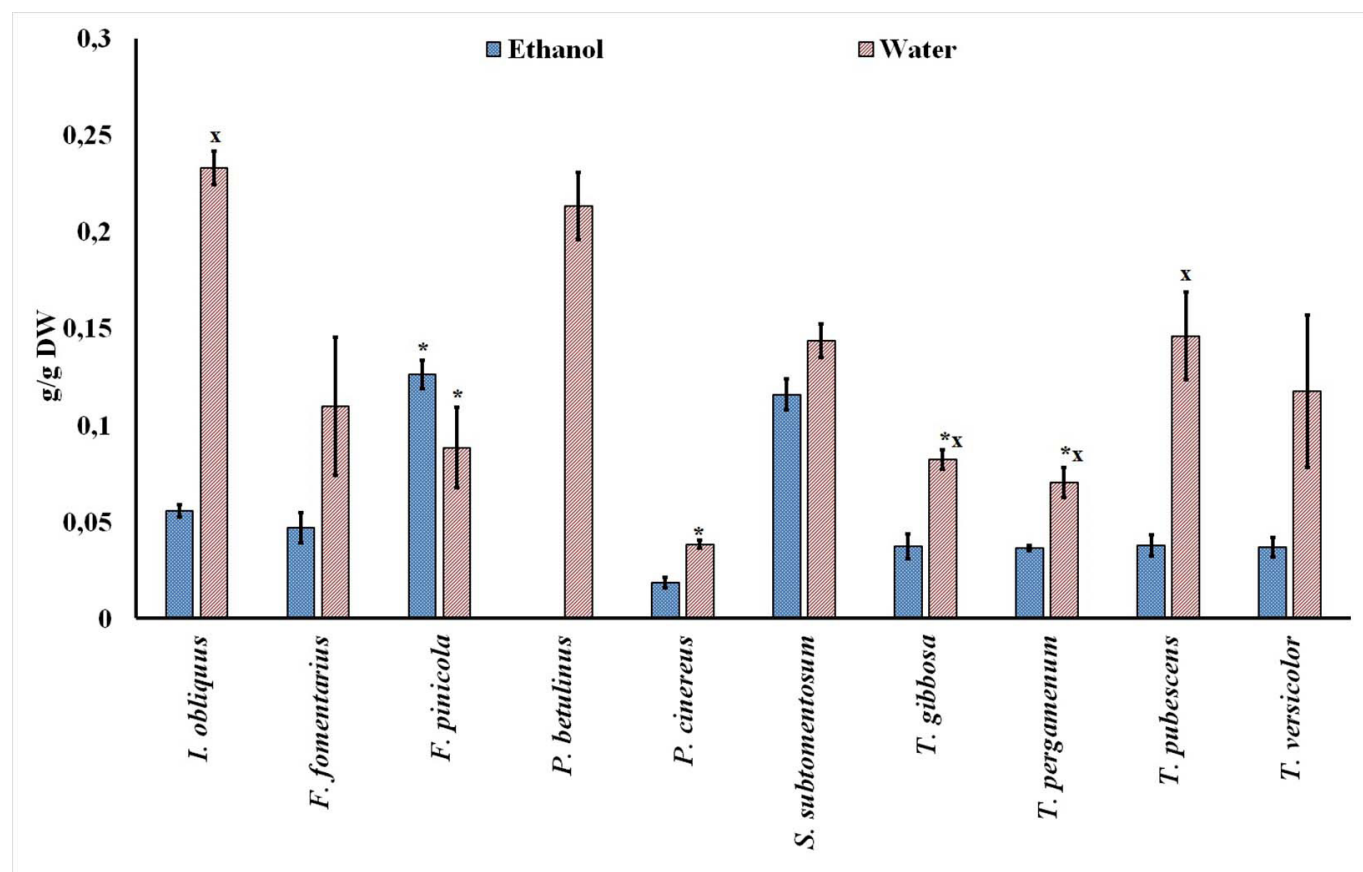

b

Fig. 2. Phenols (a) and extractives (b) in water and ethanol extracts from fruiting bodies of tinder fungi. Results are expressed as mean \pm SE. Values marked by special symbols are significantly different $(p<0.05)$ from other related values: *from chaga (I. obliquus), ${ }^{\text {x from ethanol }}$ 
of saponins. Alkaloids and saponins usually have a pronounced biological activity. It makes the species rich in these compounds promising for further study, in spite of the fact that their content is not directly related to the antioxidant ability of drugs. Antiradical and antioxidant activity of extracts is manifested to a greater extent due to phenolic compounds, including flavonoids. Qualitative reactions showed the presence of flavonoids in F. fomentarius. In other species, they were not detected. However, we cannot exclude that they might be present in trace amounts, out of the detection limits of the methods used. Phenols were found only in the extracts from perennial basidiocarps and P. betulinus, while in annual basidiocarps they were not discovered, or their concentration might be lower than the detection limits of the tests (Table 2). This difference might be related to the life forms of the fungi. Species with perennial basidiocarps have to withstand many unfavorable environmental factors, therefore, they accumulate phenols that perform an antioxidant function and protect against animals and parasites. Antioxidant ability of these species is also justified by the presence of alkaloids.
Quantitative analysis showed that the total content of phenols differed in water and ethanol extracts (Fig. 2a). In chaga water extract, phenols concentration was almost 4 times higher than in the ethanol one. It is explained by the fact that chaga is rich in melanins, which are phenolic compounds soluble in water, but not in ethanol (Sushinskaya, Kurchenko, 2006). In F. pinicola, water extract also contained more phenols than alcoholic extract $-0.8 \%$. Water chaga extract contained more phenols than any other samples $-2 \%$ of dry mass. Alcoholic extracts from $F$. fomentarius and $P$. betulinus contained $1.3 \%$ and $0.8 \%$ of phenols, respectively. In alcoholic extracts from the other species, there were no more than $0.5 \%$ of phenols. Thus, water can be recommended for extraction of phenolic compounds from I. obliquus, F. pinicola and $P$. cinereus, and in the case of $F$. fomenterius, $P$. betulinus, and $T$. versicolor, phenols are extracted more efficiently with ethanol.

The qualitative composition of phenols was compared based on chromatography data (Table 3). Chaga, F. pinicola, and P. betulinus had the greatest variety of phenols: they contained at

Table 3. Chromatography of phenols in extracts from fruiting bodies of tinder fungi (similar in water and ethanol extracts)

\begin{tabular}{l|c|ccc}
\hline \multirow{2}{*}{ Species } & \multirow{2}{*}{$\begin{array}{c}\text { Number of } \\
\text { compounds }\end{array}$} & \multicolumn{3}{|c}{ Group of compounds } \\
\cline { 3 - 5 } & & $\begin{array}{c}\text { Phenolic alcohols } \\
\text { and acids }\end{array}$ & Polyphenols & Aurons \\
\hline I. obliquus & 8 & 5 & 2 & 1 \\
F. fomentarius & 5 & 3 & 2 & 0 \\
F. pinicola & 8 & 4 & 4 & 0 \\
P. betulinus & 7 & 2 & 5 & 0 \\
P. cinereus & 4 & 4 & 0 & 0 \\
S. subtomentosum & 4 & 4 & 0 & 0 \\
T. gibbosa & 4 & 3 & 1 & 0 \\
T. pubescens & 4 & 4 & 0 & 0 \\
T. versicolor & 1 & 0 & 1 & 0 \\
T. pergamenum & 2 & 1 & 1 & 0 \\
\hline
\end{tabular}


least 7-8 individual compounds. The rest of the species contained 4-5 compounds; T. versicolor and $T$. pergamenum were poorer in phenol diversity -1 and 2 spots, respectively. Species with a high total amount of phenols had a greater variety of compounds. Solvents used for chromatography of chaga extracts did not allow to separate melanins and they remained on the starting line. According to our data, phenolic acids and alcohols in chaga prevailed over polyphenols, excluding melanins. One orange fluorescent spot was identified as auron. It was not found in other species. In $F$. pinicola, phenolic alcohols and acids accounted for half of identified substances, and polyphenols accounted for the other half. In $P$. betulinus, on the contrary, polyphenols prevailed over phenolic acids and alcohols.

Flavonoids are a special group of polyphenols. The most common source of them are plants, but there is evidence of their presence in fruiting bodies of fungi (Kim et al., 2008; Payamnoor et al., 2020). Quantification (Table 4) revealed flavonoids in F. fomentarius - $0.5 \mathrm{mg} / \mathrm{g}$ DW in ethanol extract, and in water extract from chaga its concentration was about $0.2 \mathrm{mg} / \mathrm{g}$ DW. In the other species, the concentration of flavonoids did not exceed $0.05 \mathrm{mg} / \mathrm{g}$ DW.

While antioxidant activity of phenolic compounds is widely discussed in literature, amino acids are less often considered as antioxidants, although some of them contain aromatic and sulfhydryl groups potentially providing antioxidant activity. The concentration of amino acids in the extracts varied from 1.6 to $95.9 \mathrm{mg} / \mathrm{g} \mathrm{DW}$, depending on the species and solvent extraction agent (Table 4). The highest amount of free amino acids was found in P. betulinus: $3 \%$ in water and $9.5 \%$ in ethanol extracts. Among the studied species, only this one is considered conditionally edible in several East-European countries (Pleszczyńska et al., 2017). Unlike other species, it has soft, yet rather fleshy annual basidiocarps, with a high content of free amino acids. This species also showed high antioxidant activity and reducing power (Table 1, Fig. 1). In general, the content of free amino acids in the extracts was higher than that of phenolic compounds as amino acids are primary metabolites and precursors for the biosynthesis of secondary compounds.

Table 4. Concentration of amino acids and flavonoids in extracts from fruiting bodies of tinder fungi

\begin{tabular}{|c|c|c|c|c|}
\hline \multirow{2}{*}{ Species } & \multicolumn{2}{|c|}{ Amino acids, mg/g DW } & \multicolumn{2}{|c|}{ Flavonoids, $\mu \mathrm{g} / \mathrm{g} \mathrm{DW}$} \\
\hline & Ethanol & Water & Ethanol & Water \\
\hline I. obliquus & $1.6 \pm 0.5$ & $13.9 \pm 0.6^{x}$ & $31.8 \pm 3.0$ & $165.9 \pm 8.3^{x}$ \\
\hline F. fomentarius & $7.8 \pm 0.4^{*}$ & $7.6 \pm 5.3$ & $453.8 \pm 22.5^{*}$ & $15.7 \pm 2.0^{* x}$ \\
\hline F. pinicola & $8.6 \pm 0.9^{*}$ & $9.6 \pm 2.2$ & $45.8 \pm 4.1$ & N.d.* \\
\hline P. betulinus & $95.9 \pm 5.1^{*}$ & $31.8 \pm 3.9^{* \mathrm{x}}$ & $49.7 \pm 4.5$ & $45.0 \pm 4.0 *$ \\
\hline P. cinereus & $2.3 \pm 0.3$ & $7.0 \pm 1.5^{\mathrm{x}}$ & $37.3 \pm 3.1$ & $25.2 \pm 2.0 *$ \\
\hline S. subtomentosum & $20.7 \pm 0.9^{*}$ & $21.4 \pm 0.2^{*}$ & $58.2 \pm 5.4^{*}$ & N.d.*x \\
\hline T. gibbosa & $14.2 \pm 0.9^{*}$ & $7.4 \pm 5.9$ & $10.9 \pm 1.0^{*}$ & N.d.*x \\
\hline T. pergamenum & $12.1 \pm 1.7^{*}$ & $12.2 \pm 2.7$ & N.d.* & N.d.* \\
\hline T. pubescens & $31.1 \pm 4.2 *$ & $21.4 \pm 3.4^{*}$ & $9.3 \pm 1.0 *$ & $14.6 \pm 1.5^{*}$ \\
\hline T. versicolor & $6.8 \pm 1.7 *$ & $14.3 \pm 3.7$ & $7.3 \pm 0.7 *$ & $5.9 \pm 1.0 *$ \\
\hline
\end{tabular}

Note. Results are expressed as mean \pm SE. N.d. - the compound was not detected. Values marked by special symbols are significantly different $(p<0.05)$ from other related values: *from chaga $($ I. obliquus $),{ }^{\text {x }}$ from ethanol. 
The comparison of antioxidant activity of the extracts (Table 1, Fig. 1) and the content of metabolites (Table 4, Fig. 2a) did not reveal a direct relationship between these characteristics. For example, a decrease in the content of phenols in aqueous extract from $F$. fomentarius led to a decrease of NO-scavenging and ABTS-inhibition, while for $P$. betulinis it led to an increase in these values. For $P$. betulinus, antioxidant activity, probably, was associated not with phenolic compounds, but with some other group of substances, perhaps amino acids that this species was rich in.

The nutritional value of different amino acids varies, so it is important to qualify them. Table 5 shows the results of paper chromatography of free amino acids. No difference was found in the composition of water and ethanol extracts, so the table includes unified data. The fruiting bodies of fungi contained from 4 to 8 individual amino acids, including essential ones. All investigated species contained non-proteinogenic amino acid ornithine due to the ornithine cycle as the way of urea synthesis in fungi. Among the essential amino acids, lysine was found in all species and cysteine was found in all except chaga. Methionine, leucine, phenylalanine, and tryptophan were rarely found. Histidine was not detected at all. Among the nonessential amino acids, alanine and arginine were detected. A sulfur-containing amino acid, cysteine was found in all fungi, excluding chaga; tyrosine, containing a phenyl radical was found in 8 species. These amino acids can act as antioxidants, as well as chelating agents for heavy metals. This confirms the assumption that antioxidant and antiradical activity of the extracts may be associated not only with phenolic compounds, but also with free amino acids. P. betulinus, which had the highest content of free amino acids, turned out to be one of the poorest in terms of the variety of essential amino acids - only 4 of them were identified. However, three of them possess antioxidant activity.

Table 5. The qualitative composition of amino acids in extracts from fruiting bodies of tinder fungi (similar in water and ethanol extracts)

\begin{tabular}{|c|c|c|c|c|c|c|c|c|c|c|c|c|c|}
\hline \multirow[b]{2}{*}{ Species } & \multicolumn{9}{|c|}{ Essential } & \multicolumn{3}{|c|}{ Nonessential } & \multirow[b]{2}{*}{ Total } \\
\hline & 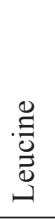 & 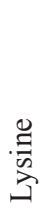 & 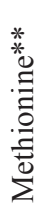 & 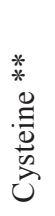 & 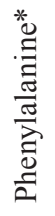 & 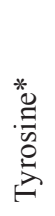 & 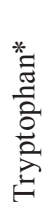 & $\stackrel{\mathscr{\Xi}}{\stackrel{\Xi}{\Xi}}$ & 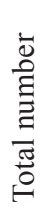 & $\underset{\stackrel{\Xi}{\Xi}}{\stackrel{\Xi}{\Xi}}$ & 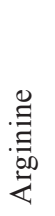 & 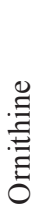 & \\
\hline I. obliquus & & + & & & & + & & & 2 & + & & + & 4 \\
\hline F. fomentarius & & + & & + & & + & + & + & 5 & + & + & + & 8 \\
\hline F. pinicola & & + & & + & + & & + & & 4 & + & + & + & 7 \\
\hline P. betulinus & & + & + & + & & + & & & 4 & + & + & + & 7 \\
\hline$P$. cinereus & & + & + & + & & + & & + & 5 & & + & + & 7 \\
\hline S. subtomentosum & & + & & + & & + & & + & 4 & + & + & + & 7 \\
\hline T. gibbosa & + & + & & + & & + & & + & 5 & + & + & + & 8 \\
\hline T. pubescens & + & + & & + & + & + & & + & 6 & & + & + & 8 \\
\hline T. versicolor & + & + & + & + & & & & & 4 & + & + & + & 7 \\
\hline T. pergamenum & + & + & & + & & + & & & 4 & + & + & + & 7 \\
\hline
\end{tabular}

Note. $*$ - aromatic amino acids; $* *$ - sulfur-containing amino acids 
The amount of extractives is an integral indicator that is often used to characterize biological raw materials when the chemical composition of the object has not been sufficiently investigated. This fully applies to fungi. For chaga, for example, it is known that the biological activity of extracts is higher, the higher the concentration of extractives in them is (Sushinskaya, Kurchenko, 2006). The data on the amount of extractable substances are presented in Fig. 2b. More extractives were found in water extracts compared to ethanol ones. Among the water extracts, those with a higher content of extractable substances had a higher antioxidant activity. When comparing annual and perennial basidiocarps, it was noted that the variations in total extractives were less pronounced than in the concentration of phenols, amino acids and antioxidant activity. Extracts from annual basidiocarps contained more amino acids and less phenols and flavonoids than perennial ones that led to lower antiradical activity in the ABTS test, lower ability to suppress NO production and to inhibit lipid peroxidation in comparison with extracts from perennial fruiting bodies.

\section{Conclusion}

The study of the extracts from fruiting bodies of xylotrophic fungi showed that they are a promising raw material for obtaining substances with high antioxidant activity. Species with perennial basidiocarps were characterized by a greater diversity and a higher content of phenolic compounds and had a higher antioxidant activity than species with annual fruiting bodies.

Among species, the chaga mushroom, which is traditionally used in medicine, revealed the best antioxidant capacity and the highest concentration of phenols in water extracts. The highest level of phenols in ethanol extracts was found in $F$. fomentarius. Other investigated species were also shown to vary in chemical composition and antioxidant activity of water and ethanol extracts. Extracts from P. betulinus fruiting bodies were rich in free amino acids, which makes this species a promising raw material for food additives. Extracts from this fungus also showed high antiradical and antioxidant activity. $F$. fomentarius and $F$. pinicola, which contained alkaloids and saponins, also need further study for practical use. All examined species, except for $F$. fomentarius, did not contain flavonoids, or their content was below the detection limit.

Based on the above results it can be concluded that some of the xylotrophic fungi species growing on birch may be of interest as a potential natural source of antioxidants and free amino acids.

\section{References}

Blagodatski A., Yatsunskaya M., Mikhailova V., Tiasto V., Kagansky A., Katanaev V.L. (2018) Medicinal mushrooms as an attractive new source of natural compounds for future cancer therapy. Oncotarget, 9(49): 29259-29274

Brieger K., Schiavone S., Miller F. J. Jr., Krause K. H. (2012) Reactive oxygen species: from health to disease. Swiss Medical Weekly, 142: w13659

Géry A., Dubreule C., André V., Rioult J.-P., Bouchart V., Heutte N., de Pécoulas P.E., Krivomaz T., Garon D. (2018) Chaga (Inonotus obliquus), a future potential medicinal fungus in oncology? A chemical study and a comparison of the cytotoxicity against human lung adenocarcinoma cells (A549) and human bronchial epithelial cells (BEAS-2B). Integrative Cancer Therapies, 17(3): 832-843

Gruendemann C., Reinhardt J.K., Lindequist U. (2020) European medicinal mushrooms: do they have potential for modern medicine? - An update. Phytomedicine, 66: 153131 
Ho C.-Y., Kim C.-F., Leung K.-N., Fung K.-P., Tse T.-F., Chan H., Lau C. B.-S. (2005) Differential anti-tumor activity of Coriolus versicolor (Yunzhi) extract through p53- and/or Bcl-2-dependent apoptotic pathway in human breast cancer cells. Cancer Biology \& Therapy, 4(6): 638-644

Kim M.-Y., Seguin P., Ahn J.-K., Kim J.-J., Chun S.-C., Kim E.-H., Seo S.-H., Kang E.-Y., Kim S.-L., Park Y.J., Ro H.-M., Chung I.-M. (2008) Phenolic compound concentration and antioxidant activities of edible and medicinal mushrooms from Korea. Journal of Agricultural and Food Chemistry, 56(16): 7265-7270

Kotova E. E., Kotov S. A., Gontova T. M., Kotov A. G. (2020) Study of qualitative and quantitative content of amino acids in pumpkin seeds for further standardization of the herbal drug. European Pharmaceutical Journal, 67(1): 27-32

Kotkova V.M., Niemelä T., Viner I. A., Schigel D.S., Kurakov A.V. (2015) Polypore fungi: materials of the international course on ecology and taxonomy of lignicolous basidiomycetes in the Central Forest reserve. Tutorial. Helsinki, Helsinki University Printing House, 95 p. (in Russian)

Kurchenko V.P., Sushinskaya N.V., Kiseleva I. S., Ermoshin A.A. (2020) Biologically active substances in fruit bodies of wood decomposing fungi. Actual Problems of Organic Chemistry and Biotechnology. Ekaterinburg, AMB, p. 535-536 (in Russian)

Larayetan R., Ololade Z. S., Ogunmola O. O., Ladokun A. (2019) Phytochemical constituents, antioxidant, cytotoxicity, antimicrobial, antitrypanosomal, and antimalarial potentials of the crude extracts of Callistemon citrinus. Evidence-Based Complementary and Alternative Medicine, 5410923

Lindequist U., Niedermeyer T.H.J., Julich W.-D. (2005) The pharmacological potential of mushrooms. Evidence-Based Complementary and Alternative Medicine, 2(3): 285-299

Pavlovskaya N.E., Solokhina I. Yu., Gneusheva I. A. (2012) Investigation of triterpene saponins from oat roots Avena sativa L. Orel State Agrarian University Bulletin [Vestnik Orlovskogo gosudarstvennogo agrarnogo universiteta], 2: 48-50 (In Russian)

Payamnoor V., Kavosi M.R., Nazari J. (2020) Polypore fungi of Caucasian alder as a source of antioxidant and antitumor agents. Journal of Forestry Research, 31(4): 1381-1390

Pleszczyńska M., Lemieszek M.K., Siwulski M., Wiater A., Rzeski W., Szczodrak J. (2017) Fomitopsis betulina (formerly Piptoporus betulinus): the Iceman's polypore fungus with modern biotechnological potential. World Journal of Microbiology and Biotechnology, 33(5): 83

Re R., Pellegrini N., Proteggente A., Yang M., Rice-Evans C. (1999) Antioxidant activity applying an improved ABTS radical cation decolorization assay. Free Radical Biology and Medicine, 26(9-10): $1231-1237$

Shaikh J.R., Patil M.K. (2020) Qualitative tests for preliminary phytochemical screening: An overview. International Journal of Chemical Studies, 8(2): 603-608

Sheel R., Nisha K., Kumar J. (2014) Preliminary phytochemical screening of methanolic extract of Clerodendron infortunatum. IOSR Journal of Applied Chemistry, 7(1): 10-13

Sokolova O.A., Kotov A.G., Gontovaya T.N., Kotova E.E. (2018) Development of the identification method of phenolic compounds in flowers and leaves of sunflower. Pharmacy Bulletin [Vestnik farmacii], 2: 18-23 (in Russian)

Sorescu A.-A., Nuta A., Ion R.-M., Iancu L. (2018) Qualitative analysis of phytochemicals from sea buckthorn and gooseberry. Phytochemicals - Source of Antioxidants and Role in Disease Prevention. p. $161-177$ 
Storozhenko V.G., Krutov V.I., Ruokolainen A.V., Kotkova V.M., Bondartseva M.A. (2014) Identification guide for wood-destroying fungi of the Russian Plain's forests. Moscow, KMK Scientific Press, 195 p. (in Russian)

Sushinskaya N.V., Kurchenko V.P. (2006) Melanins of tinder fungi. Proceedings of the Belarusian State University. Series of Physiological, Biochemical and Molecular Biology Sciences [Trudy Belorusskogo gosudarstvennogo universiteta. Seriya: fiziologicheskie, biokhimicheskie i molekulyarnye osnovy funktsionirovaniya biosistem], 1(1): 144-155 (in Russian)

Tsai C.-C., Li Y.-S., Lin P.-P. (2017) Inonotus obliquus extract induces apoptosis in the human colorectal carcinoma's HCT-116 cell line. Biomedicine \& Pharmacotherapy, 96: 1119-1126

Umamaheswari M., Chatterjee T.K. (2008) In vitro antioxidant activities of the fractions of Coccinia grandis L. leaf extract. African Journal of Traditional, Complementary, and Alternative Medicines, 5(1): 61-73

Zhao C., Zhang C., Xing Z., Ahmad Z., Li J.-S., Chang M.-W. (2019) Pharmacological effects of natural Ganoderma and its extracts on neurological diseases: A comprehensive review. International Journal of Biological Macromolecules, 121: 1160-1178 